ks. Jerzy Adamczyk

Wyższe Seminarium Duchowne w Radomiu

\title{
Urząd moderatora kurii diecezjalnej
}

Biskup diecezjalny w sprawowaniu swej władzy względem powierzonego mu Kościoła partykularnego posługuje się wieloma organami pomocniczymi, wśród których centralne miejsce zajmuje kuria diecezjalna, czyli zespół instytucji i osób świadczących biskupowi pomoc w zarządzaniu całą diecezją, zwłaszcza w kierowaniu działalnością pasterską, w administrowaniu diecezją i wykonywaniu władzy sądowniczej ${ }^{1}$.

Zespół ten w ciągu wieków podlegał daleko idącej ewolucji. Na jej kształt miały wpływ różnorodne czynniki. Zasadniczy jej model wyznaczały normy prawa powszechnego, jednak biskupi poszczególnych Kościołów partykularnych, konkretyzując ten model, dostosowali przy tym w większym lub mniejszym stopniu zasady organizacji. Ażeby kuria diecezjalna mogła swoje zadania spełniać efektywnie, powinna być zespołem ludzi i organów należycie zorganizowanym. Kanon $473 \$ 1$ wyraźnie podkreśla, że biskup diecezjalny ma czuwać nad tym, by wszystkie sprawy związane $z$ zarządzaniem całą diecezją były odpowiednio koordynowane i zawsze skierowane ku lepszemu osiągnięciu dobra powierzonej mu części Ludu Bożego². Jednak tam, gdzie to będzie wskazane (dla skuteczniejszego działania kurii), biskup może mianować moderatora kurii, którego zadaniem będzie koordynowanie pod władzą

1 Zob. Codex Iuris Canonici auctoritate Ioannis Pauli PP. II promulgatus. Kodeks prawa kanonicznego, przekład polski zatwierdzony przez Konferencję Episkopatu [dalej: KPK], Poznań 1984, kan. 469.

2 Por. G. Read, Commentary to can. 473-474, w: The canon law letter and spirit a practical guide to the code of canon law. Prepared by the canon law society of Great Britain and Ireland in association with The Canadian Canon Law Society, ed. F. Morrisey, London 1999, s. 263. 
biskupa załatwianych w kurii spraw administracyjnych, jak i czuwanie nad tym, by pozostali pracownicy kurii właściwie wypełniali powierzone sobie funkcje ${ }^{3}$. W niniejszym wykładzie uwaga zostanie skierowana na instytucję kanoniczną moderatora kurii diecezjalnej, jaka jest nakreślona w kodeksie prawa kanonicznego promulgowanym przez papieża Jana Pawła II 25 stycznia 1983 roku oraz doprecyzowana w prawie partykularnym, a także w doktrynie.

\section{Moderator kurii diecezjalnej - nowy organ w strukturze kurii diecezjalnej}

W skład kurii diecezjalnej wchodzi wiele różnych organów władzy i osób, które są skierowane do wspomagania biskupa diecezjalnego w zarządzaniu diecezją. Dlatego absolutnie konieczne jest, aby w całej swej działalności dążyły one do wspólnego celu. Zarządzanie diecezją polega przede wszystkim na tym, aby wszystkie osoby wchodzące w skład kurii diecezjalnej działały dla dobra wspólnego Kościoła partykularnego. Jest rzeczą konieczną, aby ich działalność była skoordynowana. Koordynacja staje się niezbędna z różnych powodów: jest koniecznym kryterium zarządzania, pozwala znacznie lepiej wyrażać komunię (jedność) kościelną oraz unikać niepotrzebnych, rozproszonych albo nawet sprzecznych działań ${ }^{4}$. Obowiązek takiej koordynacji spoczywa przede wszystkim na biskupie diecezjalnym ${ }^{5}$. Koordynacja ta ma dwa aspekty ukazane w kan. 473. Pierwszy z nich to koordynacja ogólna administracji diecezjalnej rozumianej w sensie szerokim (kan. $473 \$ 1$ ). Obowiązek biskupa

3 Por. kan. $473 \$ 2$; J. Krukowski, Struktura kurii diecezjalnej wedtug nowego Kodeksu Prawa Kanonicznego, „Kościół i Prawo” 6 (1989), s. 43 i 45. W kan. 473 KPK zaproponowano trzy instytucje dla koordynowania duszpasterskiej i administracyjnej działalności kurii diecezjalnej, mianowicie: biskupa diecezjalnego, moderatora i radę biskupią. Por. S. Karambai, Ministers and Ministries in the Local Church. A Comprehensive Guide to Ecclesiastical Norms, Mumbai 2005, s. 74.

4 Zob. kan. 65.

5 Por. J. Krukowski, Komentarz do kan. 473, w: Komentarz do Kodeksu Prawa Kanonicznego. T. 2. Ks. II (1). Lud Boży, red. J. Krukowski, Poznań 2005, s. 349-350; A. Viana, Comentario al can. 473, w: Comentario exegético al Código de Derecho Canónico, obra dirigida y coordinada por A. Marzoa, J. Miras, R. Rodríguez-Ocaña, vol. 2, Pamplona 1996³', s. 1047. Barbara A. Cusack zauważa, że bez względu na prostotę albo złożoność struktury kurialnej, ilekroć dwie albo więcej osób albo urzędów działa, służąc wspólnemu celowi, do którego osiągania zostały one powołane w kurii jako całości, koordynacja ich działalności jest konieczna. Również biskup diecezjalny jest zobowiązany czuwać, aby wszystkie dzieła apostolatu były skoordynowane (kan. $394 \$ 1$ ). Zob. Commentary of the can. 473, w: New Commentary on the Code of Canon Law, ed. by J. Beal, J. Coriden, T. Green, New York 20oo, s. 625 . 
w tym zakresie będzie konkretyzował się w popieraniu jednolitości działalności administracyjnej poprzez wydawanie norm ogólnych i aktów szczególnych. Drugi aspekt dotyczy osobistego koordynowania przez biskupa działalności pastoralnej swoich wikariuszy administracyjnych (kan. $473 \$ 2$ ). Fundament tego obowiązku biskupa tkwi w różnych możliwościach (zakresie zadań) urzędów wikariuszy (nade wszystko w diecezjach większych), a szczególnie w fakcie kanonicznym, że funkcje wikariuszy biskupich nie są hierarchicznie sobie podporządkowane ${ }^{6}$.

Gordon Read stwierdza, że w wirze współczesnego życia rosnący wciąż w niektórych diecezjach ciężar codziennej administracji jest tak duży, że uniemożliwia biskupowi odpowiednie zajęcie się innymi, a nawet ważniejszymi zadaniami jego urzędu, tak szczegółowo przedstawianymi w kan. 375, 383-387, 396-397 itp. W tego rodzaju okolicznościach pomoc moderatora kurii - który oczywiście musi ściśle współdziałać z biskupem - może okazać się bezcenna ${ }^{7}$. Z tego powodu prawodawca kodeksowy wychodzi na przeciw tym problemom i daje biskupowi diecezjalnemu tam, gdzie to będzie wskazane, możliwość mianowania moderatora kurii, który byłby kierownikiem administracyjnym kurii ${ }^{8}$. Kuria diecezjalna jest bowiem rzeczywistością jednolitą i organicznie uporządkowaną. Fakt, że kuria jest tworzona przez różne podmioty i osoby, nie może oznaczać, że jest ona po prostu sumą organów i osób niezależnych od siebie i złączonych wyłącznie w celu pomocy biskupowi. Gdyby tak było, to nie można byłoby powiedzieć, że kuria jest rzeczywistością jednolitą, spójną. Wskazanie w kodeksie stosowności mianowania moderatora kurii z zadaniem „koordynowania pod władzą biskupa załatwianych w kurii spraw administracyjnych" potwierdza ideę, że kuria winna być postrzegana jako or-

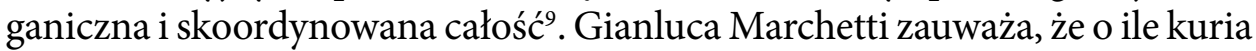

6 Por. A. Viana, Comentario al can. 473, dz. cyt., s. 1047-1048.

7 Zob. G. Read, Commentary to can. 473-474, dz. cyt., s. 263.

8 Jego funkcja jest nieco podobna do funkcji kierownika działu kadr pracowników spółki (ang. personnel manager). Por. J. San Josè Prisco, Moderator de la curia diocesana, w: Diccionario General de Derecho Canónico, obra dirigida y coordinada por J. Otaduy, A. Viana, J. Sedano, vol. 5, Pamplona 2012, s. 445.

9 Por. C. Redaelli, Natura e compiti della Curia diocesana, „Quaderni di diritto ecclesiale” 7 (1994) n. 2, s. 146-147; C. Redaelli, La Curia Diocesana: natura e articolazioni, „La Scuola Cattolica" 120 (1992) n. 2-3, s. 193. Koordynacja wymaga władzy, która faktycznie działa poprzez informację, przydział zadań i kontrolę działania organów i osób. Władza ta musi być obdarzona rzeczywistymi kompetencjami kierowniczymi, choć koordynator nie musi być koniecznie przełożonym hierarchicznym. Potrzeba koordynacji jest tym bardziej nagląca, im bardziej złożona 
określona w kodeksie nie zmieniła swojego tradycyjnego kształtu, utrzymując na przykład tradycyjne rozróżnienie sekcji administracyjnej i sądowej, o tyle włożono pewien wysiłek, aby wprowadzić nowe elementy, np. postać wikariuszy biskupich. Przede wszystkim, jednak trzeba zasygnalizować zwiększoną uwagę skierowaną na koordynację $e^{10}$ i na jednolitość działania kurii, poprzez zastosowanie zasady podwójnego podpisu ${ }^{11}$ i wprowadzenie urzędu moderatora kurii ${ }^{12}$ i rady biskupiej ${ }^{13}$.

Urząd moderatora kurii diecezjalnej jest całkowicie nowy w kodeksie z 1983 roku $^{14}$, chociaż już wcześniej istniały co najmniej dwa precedensowe przypadki uprzedzające jego wprowadzenie. Pierwszy to istnienie specjalnych koordynatorów kurii, którzy sprawowali tę funkcję w różnych częściach świata, szczególnie Europy ${ }^{15}$. Pewne europejskie diecezje wprowadziły bowiem

okazuje się administracyjna organizacja diecezji; zwłaszcza w diecezjach rozleglejszych i bardziej zaludnionych, z dużą liczbą spraw i dokumentów oraz z kurią centralną, która scala różne urzędy. W diecezjach mniejszych, z organizacją administracyjną mniejszych rozmiarów albo bardziej zdecentralizowaną problem koordynacji nie narzuca się z tą samą intensywnością. Por. A. Viana, Comentario al can. 473, dz. cyt., s. 1047.

10 Zob. kan. $473 \$ 1$.

11 Zob. kan. 474.

12 Zob. kan. $473 \$ 2-3$.

${ }_{13}$ Zob. kan. $473 \$ 4$; G. Marchetti, La curia come organo di partecipazione al ministero pastorale del vescovo diocesano,,Periodica de re canonica” 89 (2000) fasc. 4, s. 583; por. A. Viana, Comentario al can. 473 , dz. cyt., s. 1047.

${ }^{14}$ Urząd moderatora kurii wymieniony w kan. 473 jest nowy w kościelnym prawie powszechnym. Jego bliskich poprzedników trzeba poszukać w prawie partykularnym, a bardziej konkretnie w urzędzie sekretarza generalnego obecnej w różnych kuriach diecezjalnych jeszcze przed promulgacją KPK z 1983 roku. Jemu właśnie przypisywano zadania właściwe dla sekretariatu, to znaczy koordynację administracyjną w kurii i troskę, aby wszystkie urzędy kurii spełniały wiernie swoją funkcję. Por. A. Viana, Comentario al can. 473, dz. cyt., s. 1048. Kodeks kanonów Kościołów wschodnich nie wspomina o urzędzie moderatora kurii biskupiej. Niemniej jednak kan. $243 \$ 3$ wydaje się zapewniać wystarczającą swobodę biskupowi eparchialnemu, aby taki urząd ustanowił w swojej kurii. Kan. 243 $\$ 3$ brzmi: „dla zaspokojenia potrzeb lub pożytku eparchii Biskup eparchialny może ustanowić w kurii eparchialnej również inne urzędy” (Codex Canonum Ecclesiarum Orientalium auctoritate Ioannis Pauli PP. II promulgatus, Typis Polyglottis Vaticanis 1990 oraz „Acta Apostolicae Sedis” 82 (1990), s. 1033-1363, tłumaczenie polskie: Kodeks kanonów Kościołów wschodnich, Lublin 2002); por. S. Karambai, Ministers and Ministries in the Local Church, dz. cyt., s. 74, przypis 3; R. Howes, Moderator of the Curia: new boy in Town!,,,The Jurist” 40 (1982), s. 519-522.

15 Por. J. San Josè Prisco, Moderator de la curia diocesana, dz. cyt., s. 445; M. Rivella, Il funzionamento delle Curie diocesane in Italia, „Quaderni di diritto ecclesiale” 7 (1994) n. 2, s. 181; G. Marchetti, La curia come organo di partecipazione al ministero pastorale del vescovo diocesano, dz. cyt., s. 583. W kilku diecezjach w Europie precedensy urzędu moderatora kurii były już obecne przed kodeksem 
praktyczną instytucję - centralny organ, któremu przewodniczył wikariusz generalny, mający na celu kierowanie wszystkimi sekcjami i posługami kurii diecezjalnej ${ }^{16}$. Drugi przypadek dotyczył Wikariatu Rzymu - w ramach jego restrukturyzacji przez papieża Pawła VI wprowadzono urząd moderatora kurii, zwany Praelatus Secretarius (prałat sekretarz). Sprawujący ten urząd kierował sekretariatem ogólnym i miał troszczyć się o kancelarię kurii i o akty administracyjne, miał uprawnienia w kwestiach ogólnych i personalnych, informacji i dokumentacji, koordynował pracę kurii, dbał o poradnię prawną ogólną i koordynował działanie urzędów kurialnych, szczególnie troszczył się o stałą formację duszpasterską kleru, zakonników, zakonnic i laików, którzy pracują w duszpasterstwie, i ponadto o formację i szkolenie nauczycieli i katechetów. Oprócz tego pod jego nadzorem działały urzędy: administracyjny, ewentualnie ekonomiczny, prawny i techniczny ${ }^{17}$. Urząd prałata sekretarza (czyli moderatora kurii) istnieje nadal w Wikariacie Rzymu, na mocy konstytucji apostolskiej Ecclesia in urbe Jana Pawła $\mathrm{II}^{18}$. Według tego dokumentu prałat sekretarz, mianowany przez papieża po prezentacji przez kardynała wikariusza, ma zadanie moderatora urzędów wikariatu. Jego obowiązkiem jest wspomagać kardynała wikariusza i wiceregensa w wykonywaniu ich funkcji, koordynować działania związane z załatwianiem spraw administracyjnych oraz dbać, aby inni pracownicy wikariatu wiernie wykonywali powierzone im urzędy ${ }^{19}$.

Etymologicznie słowo „moderator” pochodzi od łac. słowa moderari, co oznacza „ograniczać, kierować, rządzić”. Jest to więc osoba wyposażona w kompetencje koordynacyjne lub kierownicze w określonym zespole lub

z 1983 roku. Np. kard. Antonio Rouco Varela mówi o centralnym urzędzie w niektórych kuriach diecezjalnych Europy, któremu przewodniczył zawsze wikariusz generalny. Autor ten pisze: „centralny urząd to kierowniczy i koordynujący organ wszystkich innych urzędów i posług kurii biskupiej. Przewodniczy mu wszędzie wikariusz generalny, który funkcjonuje nieustannie w bezpośrednim i najbliższym związku z biskupem" (A. Rouco Varela, El ministerio Episcopal y la organización de la curia, w: La curia Episcopal: reforma y actualización, Salamanca 1979, s. 13).

16 Por. P. Bux, Direzione e coordinamento delle attività nella Curia Diocesana, Roma 1995, s. 221.

${ }_{17}$ Por. Paulus PP. VI, Constitutio Apostolica Vicariae potestatis in Urbe, nr 4, https:// www.vatican.va/content/paul-vi/it/apost_constitutions/documents/hf_p-vi_apc_19770106_vicariaepotestatis.html (6.01.1977), „Acta Apostolicae Sedis” 69 (1977), s. 5-18; S. Karambai, Ministers and Ministries in the Local Church, dz. cyt., s. 74; Commentario alla can. 473, w: Commento al Codice di Diritto Canonico, a cura di P. Pinto, Roma 1985, s. 557; M. Rivella, Il funzionamento delle Curie diocesane in Italia, dz. cyt., s. 181.

${ }^{18}$ Giovanni Paolo II, Costituzione Apostolica Ecclesia in Urbe. Circa il nuovo ordinamento del Vicariato di Roma (1.01.1998), art. 18-19, 24, „Acta Apostolicae Sedis” 90 (1998), s. 177-193.

19 Costituzione Apostolica Ecclesia in Urbe, art. 18. 
wspólnocie wiernych ${ }^{20}$. Termin „moderator” jest niejednoznaczny i używa się go w różnych częściach kodeksu w znaczeniach bardzo różnych (czasem oznacza superiora, czyli przełożonego, czasem arbitra - sędziego, czasem to primus inter pares lub po prostu kierownik zebrania) $)^{21}$. Ogólny termin „moderator” zastąpił nazwę caput curiae, która była używana w pracach przygotowawczych nad kan. $473^{22}$, prawdopodobnie dlatego, że wyrażenie to mogło w jakiś sposób kwestionować główną odpowiedzialność biskupa za jego kurię $e^{23}$.

José San José Prisco stwierdza, że moderator to arbiter, który koordynuje całą działalność administracyjną kurii i który zapewnia w niej jednolitość dyscypliny. Jego istnienie zależy od konkretnych okoliczności każdej diecezji, chociaż $\mathrm{z}$ reguły będzie szczególnie zalecane tam, gdzie organizacja administracyjna i duszpasterstwo są skomplikowane, tak aby kuria przez jego posługę mogła rzeczywiście i skutecznie służyć duszpasterstwu ${ }^{24}$.

Zgodnie ze schematem De Populo Dei z 1977 roku moderator kurii to osoba, która pod autorytetem biskupa diecezjalnego koordynuje pracę całej administracji diecezjalnej i troszczy się o to, aby urzędnicy kurii wypełniali swoje urzędy ${ }^{25}$. Według kan. $473 \$ 2^{26}$ moderator kurii to kapłan mianowany przez biskupa diecezjalnego tam, gdzie to jest wskazane, którego zadaniem jest

${ }^{20}$ Por. E. Wilemska, Moderator w prawie kanonicznym, w: Encyklopedia katolicka, t. 12, red. E. Ziemann, Lublin 2008, k. 1491.

${ }^{21}$ Por. J. San Josè Prisco, Moderator de la curia diocesana, dz. cyt., s. 445. Kodeks z 1983 roku wyróżnia także moderatora parafii (kan. $517 \$ 1$ ), publicznego stowarzyszenia wiernych (kan. 317), domu zakonnego sui iuris (kan. $613 \$ 1$ ) i moderatora szkoły katolickiej (kan. $806 \$ 2$ ).

${ }^{22}$ Pojęcia caput curiae używał projekt CIC z 1973 roku: „Caput Curiae nominandus est in unaquaque dioecesi. Huius constitutio necessaria videtur, ut revera coordinatio omnium laborum, sub Episcopi dioecesani auctoritate, ad effectum deducatur" (Pontificia Commissio Codici Iuris Canonici Recognoscendo, Opera Consultorum in parandis canonum schematibus, II: De Clericis De Sacra Hierarchia, „Communicationes” 5 (1973), s. 225); por. P. Bux, Direzione e coordinamento delle attività nella Curia Diocesana, dz. cyt., s. 220; A. Viana, Comentario al can. 473, dz. cyt., s. 1048.

${ }^{23}$ Por. J. San Josè Prisco, Moderator de la curia diocesana, dz. cyt., s. 445; A. Viana, Comentario al can. 473 , dz. cyt., s. 1048.

${ }^{24}$ Zob. J. San Josè Prisco, Moderator de la curia diocesana, dz. cyt., s. 445.

25 Pontificia Commissio Codici Iuris Canonici Recognoscendo, Schema De Populo Dei, Typis Polyglottis Vaticanis 1977, tekst polski: Posoborowe prawodawstwo kościelne, zebrał i przetłumaczył E. Sztafrowski, t. 10, z. 2, Warszawa 1979, can. 286. Trzeba zauważyć, że w przytoczonym Schemacie nie mówi się, że moderator ma być kapłanem. Por. G. Giuliani, I canoni generali sulla Curia diocesana, „Apollinaris” 61 (1988) nr 1-2, s. 143.

${ }^{26}$ Źródłami kan. $473 \$ 2$ jest: Concilium Oecumenicum Vaticanum II, Decretum de pastorali Episcoporum munere in Ecclesia Christus Dominus (28.10.1965), nr 25-26, „Acta Apostolicae Sedis” 58 (1966), s. 673-701, tekst polski: Sobór Watykański II, Dekret o pasterskich zadaniach biskupów 
koordynowanie pod władzą biskupa załatwianych w kurii spraw administracyjnych, jak i czuwanie nad tym, by pozostali pracownicy kurii właściwie wypełniali powierzone sobie funkcje. Identycznie określa moderatora kurii schemat KPK z $1980^{27}$ i z 1982 roku $^{28}$.

Zgodnie z Direttorio per il ministero pastorale dei vescovi „Apostolorum Successores" moderator kurii to kapłan ustanowiony przez biskupa diecezjalnego ze szczególnym zadaniem koordynowania spraw o charakterze administracyjnym i czuwania nad tym, aby personel kurii wiernie wypełniał swoje zadania ${ }^{29}$.

Projekt CIC z 1973 roku nakazywał obowiązkowe powoływanie moderatora kurii ${ }^{30}$. W schemacie De Populo Dei z 1977 roku postanawiano także, aby urząd moderatora kurii był obowiązkowy ${ }^{31}$. Natomiast schematy KPK z $1980^{32}$

w Kościele Christus Dominus [dalej: CD], w: Sobór Watykański II, Konstytucje, dekrety, deklaracje. Tekst polski. Nowe tłumaczenie, Poznań 2002, s. 236-258.

${ }_{27}$ Schema Codicis Iuris Canonici, Libreria Editrice Vaticana 1980, can. $393 \$ 2$.

${ }_{28}$ Codex Iuris Canonici. Schema novissimum iuxta placita Patrum Commissionis emendatum atque Summo Pontifici praesentatum, Typis Polyglottis Vaticanis 1982, can. $473 \$ 2$.

${ }_{29}$ Por. Congregaticio pro Episcopis, Direttorio per il ministero pastorale dei vescovi „Apostolorum Successores” (22.02.2004), nr 178, Città del Vaticano 2004, tekst polski: Kongregacja do spraw Biskupów, Dyrektorium o pasterskiej posłudze biskupów „Apostolorum Successores” [dalej: AS], Kielce 2005.

30 Zob. „Communicationes” 5 (1973), s. 225-226.

${ }^{31}$ „Notetur tamen novam introduci figuram et novum officium, scilicet officium Moderatoris Curiae” (Pontificia Commissio Codici Iuris Canonici Recognoscendo, Schema De Populo Dei, dz. cyt., can. 286); por. A. Mendonca, The structural components of the diocesan curia, „Canonical Studies" 16 (2002), http://www.canonlawsocietyindia.org (2.06.2017).

${ }^{32}$ Can. $393 \$ 2$ schematu KPK z 1980 roku postanawiał inaczej niż schemat z 1977 roku, mianowicie, że wprowadzenie urzędu moderatora kurii będzie fakultatywne. Obrady Komisji Kodyfikacyjnej odnośnie do tej kwestii pokazują, że sekretarz komisji i zespół konsultorów zdali sobie sprawę, iż urząd moderatora może nie być przydatny powszechnie. Dlatego sekretarz komisji, przedstawiając syntetycznie kanony $(285 \$ 2$ i $286 \$ 1)$ schematu KPK z 1977 roku, wyjaśnił tę zmianę następująco: „Moderator kurii nie powinien być narzucany każdej diecezji. Moderator jest na pewno użyteczny w wielkich diecezjach, lecz nie w małych. Dlatego musimy powiedzieć, że kiedy mówimy o moderatorze, stosujemy wyrażenia ograniczające, takie jak tam, gdzie to będzie celowe, (...) powinien być wprowadzony” (zob. „Commucicationes” 13 (1981), s. 115-116); por. P. Bux, Direzione e coordinamento delle attività nella Curia Diocesana, dz. cyt., s. 220-221. Z proponowaną zmianą obowiązujący charakter przepisu został sformułowany następująco „tam, gdzie to będzie wskazane, można mianować moderatora kurii” („ubi id expendiat, nominari potest Moderator curiae, qui sacerdos sit oportet” („Communicationes” 13 (1981), s. 116). Norma ta, jednomyślnie zatwierdzona przez członków Komisji Kodyfikacyjnej, jest zawarta w kanonie $473 \$ 2$ obecnego kodeksu. Ta głęboka zmiana odzwierciedla też znaczenie respektowania zasady subsydiarności, która była tak mocno uwydatniona w nauczaniu soborowym i w podstawowych zasadach regulujących 
i z 1982 roku $^{33}$ oraz obowiązujący kodeks traktują nominację moderatora kurii fakultatywnie, „tam, gdzie to będzie wskazane” („ubi id expendiat”). Komisja ds. reformy kodeksu uznała bowiem, że urząd moderatora nie powinien być bezwzględnie narzucany każdej diecezji ${ }^{34}$. Jako fakultatywny uznaje urząd moderatora kurii biskupiej także Direttorio per il ministero pastorale dei vescovi "Apostolorum Successores" ${ }^{\text {"35. }}$.

Tak zatem urząd moderatora kurii w świetle obowiązującego prawa jest urzędem fakultatywnym, tzn. pozostawia się uznaniu biskupa diecezjalnego podjęcie decyzji co do ustanowienia moderatora kurii diecezjalnej. Kanon 473 $\$ 2$ rozstrzyga, że „tam, gdzie to będzie wskazane, można mianować moderatora kurii". Jednak w sprawie mianowania moderatora kurii biskup nie może działać całkowicie arbitralnie, gdyż powinien uwzględnić potrzeby duszpasterskie. Powinien zatem roztropnie ocenić, czy sam może podołać koordynacji wszystkich organów wchodzących w skład kurii diecezjalnej, czy zadania te należy powierzyć specjalnemu organowi pomocniczemu ${ }^{36}$. W tym drugim przypadku biskup powoła moderatora kurii, który „powinien pod władzą biskupa koordynować te wszystkie sprawy, które wymagają administracyjnego załatwienia”, oraz „zatroszczyć się o to, ażeby pozostali pracownicy kurii powierzone sobie zadania należycie wypełniali" ${ }^{37}$. W przypadku, gdy biskup nominu-

rewizję kodeksu. Por. A. Mendonca, The structural components of the diocesan curia, dz. cyt.; K. McDonough, The Moderator of the Curia and Curial Coordination, Romae 1987, s. 140.

33 Zob. can. $473 \$ 2$.

${ }^{34}$ Por. S. Karambai, Ministers and Ministries in the Local Church, dz. cyt., s. 74.

35 AS 178.

${ }^{36}$ Nie znaczy to, że to urząd moderatora kurii jest mniej ważny. Norma kan. $473 \$ 1$ odzwierciedla tylko znaczenie poszanowania zasady pomocniczości. Biskup ma poważnie rozważyć konkretną sytuację jego diecezji i potrzebę skutecznego zarządzania kurią przed zdecydowaniem się na mianowanie moderatora. W celu określenia duszpasterskiej potrzeby powołania moderatora biskup mógłby skonsultować się z Radą ds. Personalnych Duchowieństwa (głównym celem tej rady [istniejącej np. w USA], która zwykle spotyka się w związku z posiedzeniami Rady Kapłańskiej, jest doradzanie biskupowi w kwestiach nominacji duchowieństwa diecezjalnego) i z Radą Kapłańską. Moderator jest z pewnością użyteczny i ważny w dużych i miejskich diecezjach. S. Karambai, Ministers and Ministries in the Local Church, dz. cyt., s. 75; por. R. Pagé, Les Églises particulières, t. 1, Montréal 1985, s. 70-72, 76. „Wikariusz generalny i moderator kurii po biskupie zajmuje pierwszą pozycję w hierarchii administracyjnej kurii, pozostają mu podporządkowane wszystkie inne urzędy tworzące kurię diecezjalną" (Estatutos de la Curia Diocesana de Asidonia-Jerez diócesis de Asidonia Jerez, art. $26 \$ 2,23$, „Boletín Oficial del Obispado de Asidonia-Jerez", Separata nr 14, https://www. diocesisdejerez.org/index..../separatas-2001-2008 (3.06.2017)).

37 Kan. $473 \$ 1$. 
je moderatora kurii, koordynacja zadań wikariuszy generalnych i wikariuszy biskupich nadal należy do zadań samego biskupa diecezjalnego. Zadaniem moderatora kurii jest bowiem koordynacja zadań pozostałych pracowników kurii ${ }^{38}$.

Jeśli chodzi o relację moderatora do urzędu wikariusza generalnego i wikariusza biskupiego, to w zakres działalności koordynacyjnej moderatora nie wchodzi aktywność wymienionych urzędników, gdyż ich praca jest koordynowana przez samego biskupa diecezjalnego. Moderatorowi nie podlega również działalność administracyjna związana z funkcjonowaniem sądu diecezjalnego, która podlega kierownictwu wikariusza sądowego ${ }^{39}$.

\section{Tytulariusz urzędu moderatora kurii biskupiej}

Zgodnie z kan. $473 \$ 3$, jeśli zdaniem biskupa czego innego nie doradzają okoliczności miejsca, moderatorem kurii winien być mianowany wikariusz generalny, a gdy jest kilku - jeden z nich ${ }^{40}$. Dyrektorium o pasterskiej posłudze biskupów Apostolorum Successores przypomina, że „urząd moderatora powinien być powierzony jednemu z wikariuszy generalnych, o ile szczególne okoliczności nie domagają się czegoś innego"41.

Wymóg, aby wikariusz generalny został mianowany moderatorem kurii, pozostał niezmienny od czasu, gdy urząa ten został wprowadzony do pierwszego

${ }^{38}$ Por. J. Krukowski, Struktura kurii diecezjalnej według nowego Kodeksu Prawa Kanonicznego, dz. cyt., s. 52.

${ }_{39}$ Por. J. Krukowski, Komentarz do kan. 473, w: Komentarz do Kodeksu Prawa Kanonicznego. T. 2. Ks. II (1). Lud Boży, dz. cyt., s. 350 .

${ }^{40} \mathrm{~W}$ diecezjach Hiszpanii, Włoch i Francji funkcje moderatora kurii wykonuje zwykle wikariusz generalny diecezji. Por. A. Viana, Comentario al can. 473, dz. cyt., s. 1048-1049. W Stanach Zjednoczonych Ameryki moderatorem jest kanclerz kurii; zob. „Commucicationes” 13 (1981), s. 122; por. A. Perlasca, La funzione notarile del cancelliere e degli altri notai della curia, „Quaderni di diritto ecclesiale" 14 (2001) n. 2, s. 132. Jeżeli moderatorem został zamianowany wikariusz generalny, jego kompetencje administracyjne zostają znacznie rozszerzone o zadania koordynacyjne. Może on wtedy nie tylko stanowić akty administracyjne, lecz także podejmować decyzje koordynacyjne dotyczące działalności wszystkich pozostałych pracowników kurii. Wyłączone spod jego kompetencji są tylko sprawy ściśle sądowe. Por. J. Krukowski, Struktura kurii diecezjalnej wedtug nowego Kodeksu Prawa Kanonicznego, dz. cyt., s. 52-53.

${ }^{41}$ AS 178. Np. Statuto della Curia Diocesana della diocesi di Albenga-Imperia postanawia, że „kierownictwo kurii należy do wikariusza generalnego, któremu powierzana jest funkcja moderatora kurii według kan. $473 \$ 2$. Biskup może zlecić tę funkcję także innemu urzędnikowi kurii”. Art. 14, s. 3, http://repertoriogiuridico.chiesacattolica.it/statuto-della-curia-della-diocesidi-albenga-imperia (3.06.2017). 
projektu kanonu w 1973 roku $^{42}$. W historii instytucji kurii diecezjalnej wikariusz generalny zawsze odgrywał ważną rolę. Soborowy dekret Christus Dominus w nr 27 opisał urząd wikariusza generalnego jako „naczelny” w kurii diecezjalnej. Dlatego było czymś naturalnym, że z powodu jego pozycji w kurii diecezjalnej wikariusz generalny - jako wikariusz biskupa - jawił się jako pierwszy wśród innych i należało wziąć go pod uwagę przy mianowaniu moderatora kurii ${ }^{43}$. Jednak norma o wikariuszu generalnym jako moderatorze nie ma charakteru bezwzględnego.

Kanon $286 \$ 2$ schematu z 1977 roku zobowiązał biskupa do mianowania wikariusza generalnego (jeśli jest kilku wikariuszy generalnych, to jednego z nich) jako moderatora, ,jeżeli okoliczności miejscowe nie sugerują czego innego". Można byłoby odczytać tę regulację jako wyjątkową, umożliwiającą mianowanie na urząd moderatora kapłana, diakona albo nawet laika. Ale schemat z 1980 roku wyeliminował taką możliwość przez stwierdzanie, że moderator „(...) musi być kapłanem (...)”44. Ten wymóg pozostawia biskupowi pewną możliwość, kiedy konkretne okoliczności jego Kościoła partykularnego wymagają tego, by wyznaczyć sacerdos (różnego od wikariusza generalnego) na urząd moderatora kurii. Dlatego jest całkiem możliwe, że na skutek sytuacji diecezji czy warunków personalnych wymóg, aby wikariusz generalny był moderatorem, nie będzie spełniony. Biskup może więc swobodnie mianować kogoś innego jako moderatora kurii. Zamiast wikariusza generalnego może być prawnie mianowany moderatorem kurii wikariusz biskupi ${ }^{45}$ Czy inny kapłan ${ }^{46}$. Dyrektorium Apostolorum Successores przypomina, że „urząd moderatora powinien być powierzony jednemu $\mathrm{z}$ wikariuszy generalnych, o ile szczególne okoliczności nie domagają się czegoś innego; w każdym razie moderatorem powinien być kapłan"47.

${ }^{42}$ Zob. „Commucicationes” 5 (1973), s. 225.

${ }^{43}$ Por. S. Karambai, Ministers and Ministries in the Local Church, dz. cyt., s. 76; A. Mendonca, The structural components of the diocesan curia, dz. cyt.

${ }^{44}{ }(\ldots)$ qui sacerdos sit oportet, (...)” („Commucicationes” 13 (1981), s. 116); por. J. Arrieta, Diritto dellorganizzazione ecclesiastica, Milano 1997, s. 401.

45 Por. A. Mendonca, The structural components of the diocesan curia, dz. cyt.

${ }^{46}$ Biskup diecezjalny może mianować moderatorem prezbitera niebędącego wikariuszem generalnym. Taka sytuacja może mieć miejsce w większych diecezjach, w których aparat administracyjny i duszpasterski jest tak rozbudowany, iż powierzenie wikariuszowi generalnemu zadań koordynacyjnych byłoby przeszkodą w wykonywaniu zadań administracyjnych. Por. J. Krukowski, Struktura kurii diecezjalnej wedtug nowego Kodeksu Prawa Kanonicznego, dz. cyt., s. 53.

47 AS 178. 
Prawo wyraża się jasno, że moderatorem powinien być kapłan (prezbiter) ${ }^{48}$. Kanon $473 \$ 2$ używa wyrazu oportet (łac. oportere), aby mocniej podkreślić zasadę, że to kapłan powinien piastować urząd moderatora. Wyraz oportet oznacza bowiem: „należy, potrzeba, wypada, powinno się" ${ }^{49}$. Stąd Roch Pagé mówi: „wydaje się jednak, że jest to słuszne, ponieważ nawet jeśli funkcja moderatora nie zależy od sakramentu święceń, to jednak kodeks przewiduje, że powinna zostać powierzona wikariuszowi generalnemu"so. Innymi słowy, stanowisko prawodawcy jest jasne w tym punkcie: urząd moderatora pociąga za sobą taki udział w biskupiej funkcji decydowania i kontroli, że tylko ktoś, kto jest w stanie posiadać i sprawować biskupią władzę rządzenia, może pełnić ten urząd. Taką osobą winien być wikariusz generalny albo wikariusz biskupi, albo ktoś, kto posiada wymagane przymioty, aby być takim wikariuszem, to znaczy kapłan ${ }^{51}$.

Jeśli chodzi o kwalifikacje, jakie winien posiadać moderator kurii, to wydaje się, że winny być one takie jak wikariusza generalnego czy biskupiego ${ }^{52}$. Według kan. $478 \$ 1$ wikariusz generalny i biskupi powinni być kapłanami. To wymagane jest do ważności powierzenia urzędu, jak wynika z kan. 150 $0^{53}$. Ponadto, urząd

${ }^{48}$ Zob. kan. $473 \$ 2$; AS 178.

49 A. Jougan, Słownik kościelny łacińsko-polski, Warszawa 1992, s. 468; zob. A. Viana, Comentario al can. 473 , dz. cyt., s. 1048 .

5o R. Pagé, Les Églises particulières, dz. cyt., s. 66. Konsekwentnie moderatorem kurii nie może być ani laik, ani diakon.

${ }_{51}$ Por. R. Conlon, The moderator of the curia as manager of the diocesan pastoral action, Ottawa 1987, s. 140; A. Mendonca, The structural components of the diocesan curia, dz. cyt.; R. Pagé, Les Églises particulières, dz. cyt., s. 68 i 72; W. Aymans, Der Leitungsdienst des Bischofs im Himblick auf die Teilkirche. Über die bischöfliche Gewalt und ihre Ausübung auf Grund des Codex Iuris Canonici, "Archiv für katholisches Kirchenrecht” 153 (1984), s. 48. Antonio Viana jest zdania, że chociaż teoretycznie wszystkie czynności moderatora mogłyby być spełniane przez jakiegokolwiek wiernego należycie przygotowanego, to jednak prawo uważa za stosowne (oportere), aby moderator był kapłanem. Ten warunek wydaje się wynikać z praktycznych powodów, takich jak na przykład: pożytek, gdyż z reguły wikariusz generalny spełnia funkcje moderatora (a wikariusz generalny musi być kapłanem, według kan. $478 \$ 1$ ); fakt, że moderator jest przeznaczony do kierowania działalnością urzędów kurii spełnianych przez duchownych; gwarancja właściwej formacji, którą zakłada kapłaństwo ministerialne; fakt, że zwykle wynagrodzenie ekonomiczne jest mniejsze w wypadku duchownych niż w przypadku laików. Zob. A. Viana, Comentario al can. 473, dz. cyt., s. 1048.

${ }^{52}$ Kodeks określa tylko kwalifikacje, jakie powinni mieć wikariusz generalny i biskupi. Odnośnie do kwalifikacji moderatora wymaga jedynie, aby był on kapłanem. Por. J. Arrieta, Diritto dellorganizzazione ecclesiastica, dz. cyt., s. 410.

${ }^{53}$ Interesujące rozważania dotyczące kwestii możliwości powołania wiernego świeckiego na urząd moderatora kurii można znaleźć w: S. Karambai, Ministers and Ministries in the 
wikariusza generalnego czy biskupiego teologicznie koresponduje z urzędem biskupa diecezjalnego jako jego alter ego w funkcjach pasterskich i wykonawczych. Dalej, kapłani ci winni ukończyć przynajmniej trzydzieści lat, posiadać doktorat lub licencjat $\mathrm{z}$ prawa kanonicznego lub $\mathrm{z}$ teologii, ewentualnie być $\mathrm{w}$ tych dyscyplinach przynajmniej naprawdę biegli ${ }^{54}$, odznaczać się zdrową nauką, prawością, roztropnością i doświadczeniem w załatwianiu spraw ${ }^{55}$.

Dyrektorium o pasterskiej posłudze biskupów Apostolorum Successores postanawia, że „biskup może mianować wikariuszem generalnym lub wikariuszami biskupimi kapłanów wiernych pod względem doktrynalnym, godnych zaufania, szanowanych przez prezbiterium i opinię społeczną, mądrych, uczciwych i prawych w obyczajach, posiadających doświadczenie duszpasterskie i administracyjne, zdolnych do nawiązywania autentycznych relacji międzyludzkich oraz umiejących zająć się sprawami diecezji. Powinni mieć ukończone przynajmniej 30 lat, jakkolwiek roztropnie by było, tam gdzie to możliwe, aby mieli ukończone lat 40. Powinni też posiadać odpowiednie wykształcenie uniwersyteckie, potwierdzone doktoratem lub licencjatem z prawa kanonicznego lub z teologii, ewentualnie w tych dyscyplinach winni być przynajmniej rzeczywiście biegli" ${ }^{56}$.

W przypadku gdy moderatorem kurii jest wikariusz generalny czy biskupi, to nie powinni być oni kanonikami penitencjarzami i krewnymi biskupa, aż do czwartego stopnia ${ }^{57}$. Wydaje się, że także, gdyby inny kapłan, różny od wikariusza generalnego czy biskupiego został moderatorem kurii, to również winien spełniać te wymogi. Sebastian Karambai słusznie zauważa, że chociaż urzędy kościelne, takie jak proboszcza czy wikariusza sądowego nie są wewnętrznie

Local Church, dz. cyt., s. 75-76; por. G. Giuliani, I canoni generali sulla Curia diocesana, dz. cyt., s. $143-144$.

${ }^{54},(. .$.$) posiadają doktorat lub licencjat z prawa kanonicznego lub z teologii, ewentualnie$ w tych dyscyplinach są przynajmniej naprawdę biegli” (kan. $478 \$ 1$ ). Celem tej klauzuli jest pewność, że osoba przyjmująca ten urząd, jest naprawdę kompetentna z punktu widzenia zdrowej formacji - zarówno duszpasterskiej, jak i akademickiej. Wiedza specjalistyczna powinna być nabyta szczególnie w dziedzinie prawa kanonicznego i teologii. Sformułowania „ewentualnie w tych dyscyplinach są przynajmniej naprawdę biegli” nie należy interpretować jedynie jako escape clause („klauzula zwalniająca od odpowiedzialności”) ani jako luźnego (otwartego) wymogu, który obejmowałoby wiedzę w dziedzinie innych nauk, takich jak socjologia, opieka zdrowotna, edukacja itp. Por. S. Karambai, Ministers and Ministries in the Local Church, dz. cyt., s. 79.

55 Por. S. Karambai, Ministers and Ministries in the Local Church, dz. cyt., s. 78-79.

${ }^{56}$ AS 179.

57 Zob. kan. $478 \$ 2$. 
(samoistnie) niezgodne z urzędem wikariusza generalnego czy biskupiego, to ich łączenie nie jest pożądane, ponieważ obowiązki jednego urzędu mogą poważnie utrudnić wypełnianie obowiązków drugiego. Sformułowanie ,jeden człowiek, jedna praca" powinno być podstawową regułą również w kościelnym zarządzaniu ${ }^{58}$. Konsekwentnie nie powinno się łączyć urzędu proboszcza czy wikariusza sądowego z funkcją moderatora kurii, w przypadku gdy jest on kapłanem różnym od wikariusza generalnego czy biskupiego.

Gdy chodzi o kwestie nominacji moderatora kurii, to prawo wypowiada się jednoznacznie: biskup diecezjalny może również ustanowić moderatora kurii diecezjalnej tam, „gdzie zachodzi potrzeba”, którą ocenia sam biskup. Jest to konsekwencja innego przepisu kodeksowego. Kanon 470 przypomina, że „nominacja tych, którzy sprawują urzędy w kurii diecezjalnej, należy do biskupa diecezjalnego". Organem kompetentnym do mianowania osób na urzędy w kurii diecezjalnej, w tym moderatora, jest biskup diecezjalny, gdyż mają one spełniać zadania w jego imieniu, dla dobra całej diecezji. Nominacja urzędników kurii jest aktem administracyjnym, którego stanowienie wchodzi w zakres swobodnego uznania biskupa diecezjalnego ${ }^{59}$. Takie same kompetencje w tym zakresie jak biskupowi diecezjalnemu przysługują zwierzchnikom Kościotów partykularnych, zrównanych $\mathrm{z}$ biskupem diecezjalnym ${ }^{60}$. Dyrektorium o pasterskiej posłudze biskupów Apostolorum Successores stanowi, że „biskup może również ustanowić urząd moderatora kurii”" ${ }^{\prime 1}$. Administrator diecezji nie ma władzy mianowania na wszystkie urzędy kurialne, np. nie może mianować wikariusza generalnego ani wikariusza biskupiego ${ }^{62} \mathrm{czy}$ moderatora.

Choć kodeks milczy na temat usunięcia moderatora, to przez analogię do kan. 485, gdzie jest mowa o tym, że „kanclerz i notariusze mogą być swobodnie usunięci z zajmowanego stanowiska przez biskupa diecezjalnego", należy stwierdzić, że biskup diecezjalny może swobodnie usunąć moderatora. Trzeba jednak zaznaczyć, że musiałaby istnieć ku temu poważna przyczyna, gdyż jego stanowisko ma duże znaczenie w funkcjonowaniu diecezji. Administrator diecezjalny może tego dokonać tylko za zgodą kolegium konsultorów. Usunięcie moderatora może nastąpić „,swobodnie”, czyli zgodnie z wymogami

\footnotetext{
${ }_{58}$ Zob. S. Karambai, Ministers and Ministries in the Local Church, dz. cyt., s. 79.

59 Por. kan. 157; J. Arrieta, Diritto dell'organizzazione ecclesiastica, dz. cyt., s. 400-401.

${ }^{60}$ Por. kan. 370-371.

${ }^{61}$ AS 178 .

${ }^{62}$ Por. J. Krukowski, Komentarz do kan. 470, w: Komentarz do Kodeksu Prawa Kanonicznego.
} T. 2. Ks. II (1). Lud Boży, dz. cyt., s. 347 . 
dotyczącymi sprawowania władzy dyskrecjonalnej, przysługującej rządcom diecezji w postępowaniu administracyjnym. W postępowaniu tym należy uwzględnić fakt „zaistnienia słusznej przyczyny”, której osąd ustawodawca pozostawia roztropnej ocenie rządcy diecezji. W tym celu konieczne jest przeprowadzenie postępowania dowodowego. Przyczyna uzasadniająca usunięcie $\mathrm{z}$ urzędu kanclerza lub notariusza może mieć miejsce, gdy tytulariusz urzędu sprawuje go bezowocnie bądź ze szkodą dla diecezji ${ }^{63}$.

\section{Zadania moderatora kurii diecezjalnej}

Urząd moderatora jest fakultatywny, nienakazany. W kurii diecezjalnej jest on urzędem administracyjnym, niebędącym bezpośrednio związanym z sądem biskupim. Władza moderatora jest zastępcza, działa on zawsze „pod władzą biskupa diecezjalnego", uczestnicząc w jego władzy wykonawczej ${ }^{64}$. Z tego powodu sam kodeks poleca, aby z reguły moderatorem był mianowany wikariusz generalny ${ }^{65}$ albo inny kapłan, ponieważ koordynuje on działalność funkcji spełnianych w zasadniczej większości przez duchownych ${ }^{66}$. Funkcja moderatora kurii ma charakter techniczno-administracyjny. Pod władzą biskupa dba on o właściwe funkcjonowanie i współpracę różnych urzędów ${ }^{67}$. Moderator różni się od wikariusza generalnego, pozostaje pod jego władzą, a także pod autorytetem biskupa, ponieważ wikariusz generalny „zajmuje w kurii diecezjalnej czołowe stanowisko" ${ }^{68} \mathrm{i}$ w całej diecezji jego władza zwyczajna przypada mu bezpośrednio (natychmiast) po biskupie ${ }^{69}$.

Zgodnie z kan. $473 \$ 2$ zadaniem moderatora kurii jest koordynowanie pod władzą biskupa załatwianych w kurii spraw administracyjnych, jak i czuwanie nad tym, by pozostali pracownicy kurii właściwie wypełniali powierzone im funkcje (funkcja kontrolna).

Odnośnie do pierwszej kompetencji, czyli koordynowania pod władzą biskupa załatwianych w kurii spraw administracyjnych, powołanie moderatora ma na celu usprawnienia działalności administracyjnej kurii. Moderator

${ }^{63}$ Por. Krukowski J., Komentarz do kan. 485, w: Komentarz do Kodeksu Prawa Kanonicznego. T. 2. Ks. II (1). Lud Boży, dz. cyt., s. 368.

${ }^{64}$ Por. kan. $473 \$ 2$.

${ }^{65}$ Por. kan. $473 \$ 3$.

${ }^{66}$ Zob. AS 178; por. J. San Josè Prisco, Moderator de la curia diocesana, dz. cyt., s. 445-446.

${ }_{67}$ Zob. Commentario alla can. 473, dz. cyt., s. 557.

${ }^{68} \mathrm{CD} 27$.

${ }^{69}$ Zob. Commentario alla can. 473, dz. cyt., s. 557. 
koordynuje wszystkie sprawy kurii wymagające rozpatrzenia w trybie administracyjnym (wyłączone spod jego kompetencji są sprawy załatwiane w trybie sądowym i kwestie ekonomiczne) ${ }^{70}$. Jego działalność koordynująca w zakresie administracji będzie polegać m.in. na studiowaniu akt, rozwiązaniu konfliktów kompetencji, intensyfikowaniu pracy itd.

W szczególności obowiązkiem moderatora jest: zorganizowanie przede wszystkim tego wszystkiego, co związane jest z infrastrukturą niezbędną do prawidłowego wykonywania zadań administracyjnych kurii, zarządzanie zasobami ludzkimi i materialnymi, koordynowanie działalności administracyjnej różnych agend i instytucji, które tworzą kurię diecezjalną, zwoływanie okresowo narad z zarządzającymi wspomnianymi agendami i instytucjami i staranie się o uzyskanie od nich informacji, branie udziału w przekazywaniu i rozdzielaniu dokumentacji administracyjnej, monitorowanie prawidłowości postępowania tytulariuszy każdego z diecezjalnych urzędów administracyjnych, rozwiązywanie przypadków sporów kompetencyjnych między oficjami i przedkładanie biskupowi stosownych informacji - propozycji dekretów, zarządzeń, regulaminów i dyrektoriów - które czynią bardziej skutecznym i sprawnym działanie kurii ${ }^{71}$. Ponadto moderator opracowuje plan pracy wszystkich agend, które działają w trybie administracyjnym, oraz analizuje efektywność wykonanych zadań i poszukuje środków umożliwiających pokonywanie napotykanych trudności ${ }^{72}$.

Wreszcie, zgodnie z przepisami kodeksu, powinien być powiadamiany o aktach kurii, które powstały, by wywołać skutek prawny ${ }^{73}$, ponadto jest on tym, który gwarantuje bezpieczeństwo archiwum diecezjalnego, zezwalając wraz z kanclerzem na wejście do archiwum ogólnego i zabranie stamtąd dokumentów ${ }^{74}$.

Uszczegółowienia zadań moderatora dokonuje biskup diecezjalny w piśmie nominacyjnym lub w prawie partykularnym. Według Regulaminu Kurii Diecezjalnej w Tarnowie do szczególnych zadań moderatora kurii należy: troska o właściwe funkcjonowanie i koordynacja pracy wydziałów kurii; zwoływanie posiedzeń pracowników kurii w celu wymiany informacji oraz uzgodnienia

7o Por. E. Wilemska, Moderator w prawie kanonicznym, dz. cyt., k. 1491.

${ }^{71}$ Por. J. San Josè Prisco, Moderator de la curia diocesana, dz. cyt. s. 445.

${ }_{72}$ Por. J. Krukowski, Struktura kurii diecezjalnej według nowego Kodeksu Prawa Kanonicznego, dz. cyt., s. 53 .

${ }_{73}$ Por. kan. 474.

74 Por. kan. 487-488; J. San Josè Prisco, Moderator de la curia diocesana, dz. cyt., s. 445-446. 
zadań bieżących; wprowadzanie na urząd nowo mianowanych pracowników wydziałów; ustalanie zakresu obowiązków poszczególnych pracowników kurii oraz instytucji diecezjalnych, z zachowaniem postanowień dekretu nominacyjnego; koordynacja realizacji przedsięwzięć i zarządzeń duszpasterskich zleconych przez biskupa; zatwierdzanie, w porozumieniu z dyrektorami wydziałów, materiałów i książek, które z rozdzielnika wysyłane są do parafii i do księży ${ }^{75}$.

Zgodnie z Regulaminem Kurii Metropolitalnej Warszawskiej do zadań moderatora (zwanego tu „moderatorem wydziałów duszpasterskich”) należy: koordynacja pracy podległych mu wydziałów; przygotowanie projektu programu duszpasterskiego, który podlega zatwierdzeniu przez arcybiskupa; nadzór nad przygotowaniem uroczystości ogólnodiecezjalnych; utrzymywanie kontaktów z odpowiednimi komisjami i radami Konferencji Episkopatu Polski i innymi instytucjami ogólnopolskimi, troska o wykonanie ponaddiecezjalnych zadań duszpasterskich i ich aplikację w archidiecezji; koordynacja działalności duszpasterstw specjalistycznych archidiecezji (grup społecznych, zawodowych, duszpasterstwa akademickiego, stowarzyszeń i ruchów, duszpasterstwa trzeźwości itp.) oraz Komisji ds. Liturgii i Komisji Muzyki Kościelnej; koordynacja prac nad preliminarzem budżetowym wszystkich podległych wydziałów; prowadzenie postępowania dotyczącego udzielenia imprimatur wszelkim publikacjom o charakterze religijnym i koordynacja pracy kolegium cenzorów ustanowionych przez arcybiskupa; troska o przygotowanie „Biuletynu Duszpasterskiego"; wykonywanie innych zadań zleconych przez arcybiskupa i wikariuszy generalnych ${ }^{76}$.

Do zadań moderatora kurii stosownie do postanowień Statutu Kurii Metropolitalnej Wrocławskiej należy: troska o najbardziej owocne wykonywanie zadań powierzonych poszczególnym pracownikom kurii, zwoływanie posiedzeń pracowników kurii w celu przedstawienia i wymiany informacji oraz zadań bieżących, czuwanie nad obecnością pracowników kurialnych w pracy ${ }^{77}$. Statut Kurii Metropolitalnej Poznańskiej stwierdza, że do zadań moderatora kurii należy: troska o najbardziej owocne wykonywanie zadań powierzonych

75 Regulamin Kurii Diecezjalnej w Tarnowie (31.12.2010), nr 9, „Currenda” 161 (2011) nr 1, s. 64.

${ }^{76}$ Zob. Regulamin Kurii Metropolitalnej Warszawskiej (24.06.2008), B. cz. III, archwwa.net/ wp-content/uploads/2016/o4/regulamin (10.05.2017). Jak widać, urząd moderatora wydziałów duszpasterskich w Kurii Metropolitalnej Warszawskiej nie zawiera kompetencji kontrolnych wobec pracowników kurii. Jego kompetencje stanowią tylko część kodeksowych kompetencji moderatora.

77 Zob. Statut Kurii Metropolitalnej Wrocławskiej (9 grudnia 2013), § 1, nr 2, s. 2, http://www. archidiecezja.wroc.pl (10.05.2017). 
poszczególnym pracownikom kurii, zwoływanie posiedzeń pracowników kurii w celu przedstawiania i wymiany informacji oraz uzgadniania zadań bieżących, czuwanie nad obecnością pracowników kurialnych ${ }^{78}$. Natomiast Regulamin Legnickiej Kurii Biskupiej ustala, co następuje: do zadań moderatora kurii należy: troska o właściwe funkcjonowanie wydziałów i referatów kurii; koordynacja pracy pomiędzy wydziałami i referatami kurii; poszukiwanie sposobów i środków zapewniających najbardziej efektywne wykonywanie zadań powierzonych poszczególnym pracownikom; zwoływanie w imieniu biskupa posiedzeń pracowników kurii w celu przedstawienia i wymiany informacji oraz uzgadniania bieżących zadań; organizowanie spotkań formacyjnych dla pracowników $^{79}$.

Statuto della Curia Diocesana della diocesi di Albenga-Imperia wskazuje, że odpowiedzialność moderatora kurii dotyczy przede wszystkim zorganizowania, działania i koordynacji w odniesieniu do całej struktury kurii i personelu, którym zarządza ${ }^{80}$. Natomiast Estatuto de la curia de la Diócesis De Orihuela-Alicante postanawia, że prowikariusz generalny wspomaga biskupa pomocniczego w jego pracy wikariusza generalnego. Cieszy się władzą zwyczajną zastępczą, spod której wyłączone są te sprawy, które zarezerwował wyraźnie biskup diecezjalny albo biskup pomocniczy. Prowikariusz generalny piastuje urząd moderatora kurii, chyba że biskup diecezjalny postanowi inaczej. Jego zadania są następujące: koordynowanie działalności administracyjnej z wyjątkiem aktów administracyjnych wydawanych przez biskupa pomocniczego-wikariusza generalnego. W określonych okolicznościach, za zgodą biskupa diecezjalnego, będzie mógł tworzyć komisje dla studiowania konkretnych spraw. Ma troszczyć się, aby cały personel kurii wykonywał sumiennie swoje zadania. Stąd bierze udział w przyjmowaniu pracowników do pracy w kurii ${ }^{81}$.

${ }^{78}$ Zob. Statut Kurii Metropolitalnej Poznańskiej (14 czerwca 2008), w: LXIX Synod Archidiecezji Poznańskiej (2004-2008), nr 7, t. 2: Statuty, Poznań 2008, s. 392.

79 Zob. Regulamin Legnickiej Kurii Biskupiej, rozdz. I \$ 3, w: I Synod Diecezji Legnickiej (2007-2012), t. 1: Program odnowy religijno-moralnej, Legnica 2012, s. 280.

80 Zob. Statuto della Curia Diocesana della diocesi di Albenga-Imperia, dz. cyt., art. 15, s. 3.

${ }^{81}$ Zob. Estatuto de la curia de la Diócesis De Orihuela-Alicante, cap. 3, art. 16, s. 5 https://www. diocesisoa.org/documentos/ficheros/Estatuto_de_la_curia_de_la_Diocesis_512.pdf (1.05.2017). 


\section{Podsumowanie}

1. Kuria diecezjalna, czyli zespół instytucji i osób, które świadczą biskupowi pomoc w zarządzaniu całą diecezją, zwłaszcza w kierowaniu działalnością pasterską, w administrowaniu diecezją i wykonywaniu władzy sądowniczej, ma efektywnie spełniać swoje zadania, to natomiast wymaga należytego zorganizowania.

2. Zarządzanie diecezją polega przede wszystkim na tym, aby wszystkie osoby wchodzące w skład kurii diecezjalnej działały dla dobra wspólnego Kościoła partykularnego, stąd jest rzeczą konieczną, aby ich działalność była skoordynowana.

3. Koordynacja pracy kurii biskupiej staje się niezbędna z różnych powodów: jest koniecznym kryterium zarządzania, pozwala znacznie lepiej wyrażać komunię (jedność) kościelną oraz unikać niepotrzebnych, rozproszonych albo nawet sprzecznych działań.

4. W celu usprawnienia pracy kurii, zwłaszcza w większych diecezjach, prawodawca kodeksowy daje biskupowi diecezjalnemu tam, gdzie to będzie wskazane, możliwość mianowania moderatora kurii, który byłby kierownikiem administracyjnym kurii.

5. Choć urząd moderatora kurii w świetle obowiązującego prawa jest urzędem fakultatywnym, to jednak w sprawie mianowania moderatora kurii biskup nie może działać całkowicie arbitralnie, gdyż powinien uwzględnić potrzeby duszpasterskie. Powinien zatem roztropnie ocenić, czy sam może podołać koordynacji wszystkich organów wchodzących w skład kurii diecezjalnej, czy zadania te należy powierzyć specjalnemu organowi pomocniczemu.

6. Tytulariusz urzędu moderatora kurii diecezjalnej powinien mieć odpowiednie przymioty osobowościowe i kwalifikacje oraz doświadczenie w kwestiach organizacyjnych.

7. Najlepiej, aby moderatorem był wikariusz generalny, ewentualnie wikariusz biskupi.

8. Uszczegółowienia zadań moderatora winien dokonać biskup diecezjalny $\mathrm{w}$ piśmie nominacyjnym lub w prawie partykularnym.

\section{ABSTRAKT}

W celu usprawnienia pracy kurii biskup diecezjalny tam, gdzie to będzie wskazane, może mianować moderatora kurii diecezjalnej. Niniejszy artykuł podejmuje kwestię urzędu moderatora. 
Najpierw zwrócono uwagę na to, że moderator kurii diecezjalnej jest nowym organem w strukturze kurii diecezjalnej. Następnie przedstawiono zagadnienie osoby piastującej stanowisko moderatora kurii biskupiej. Na koniec omówiono zadania moderatora kurii diecezjalnej.

\section{SŁOWA KLUCZOWE}

urząd, kuria diecezjalna, moderator, biskup diecezjalny, wikariusz generalny

\section{Abstract}

\section{The Office of the Moderator of the Curia.}

In order to improve the curia's work, a diocesan bishop can nominate the moderator of the curia if it is necessary. This article discusses the office of the moderator of the curia. First it focuses on the fact that the moderator of the curia is a new office in the structure of the diocesan curia. Then it describes the character of the person holding the office of the moderator of the curia. Finally it outlines the duties of the moderator of the diocesan curia.

\section{KEYWORDS}

office, diocesan curia, moderator of the curia, diocesan bishop, vicar general

\section{BIBLIOGRAFIA}

\section{Źródła}

Codex Canonum Ecclesiarum Orientalium auctoritate Ioannis Pauli PP. II promulgatus, Typis Polyglottis Vaticanis 1990 oraz „Acta Apostolicae Sedis” 82 (1990), s. 1033-1363, tłumaczenie polskie: Kodeks kanonów Kościołów wschodnich, Lublin 2002.

Codex Iuris Canonici. Schema novissimum iuxta placita Patrum Commissionis emendatum atque Summo Pontifici praesentatum, Typis Polyglottis Vaticanis 1982.

Codex Iuris Canonici auctoritate Ioannis Pauli PP. II promulgatus. Kodeks prawa kanonicznego, przekład polski zatwierdzony przez Konferencję Episkopatu, Poznań 1984.

Concilium Oecumenicum Vaticanum II, Decretum de pastorali Episcoporum munere in Ecclesia Christus Dominus (28.10.1965), „Acta Apostolicae Sedis” 58 (1966), s. 673-701, tekst polski: Sobór Watykański II, Dekret o pasterskich zadaniach biskupów w Kościele Christus Dominus, w: Sobór Watykański II, Konstytucje, dekrety, deklaracje. Tekst polski. Nowe tłumaczenie, Poznań 2002, s. 236-258. 
Congregaticio pro Episcopis, Direttorio per il ministero pastorale dei vescovi „Apostolorum Successores" (22.02.2004), Città del Vaticano 2004, tekst polski: Kongregacja do spraw Biskupów, Dyrektorium o pasterskiej posłudze biskupów „Apostolorum Successores", Kielce 2005.

Estatuto de la curia de la Diócesis De Orihuela-Alicante, https://www.diocesisoa.org/ documentos/ficheros/Estatuto_de_la_curia_de_la_Diocesis_512.pdf (1.05.2017).

Estatutos de la Curia Diocesana de Asidonia-Jerez diócesis de Asidonia Jerez, „Boletín Oficial del Obispado de Asidonia-Jerez", Separata nr 14, https://www.diocesisdejerez.org/ index.../separatas-2001-2008 (1.05.2017).

Giovanni Paolo II, Costituzione Apostolica Ecclesia in Urbe. Circa il nuovo ordinamento del Vicariato di Roma (1 ianuarii 1998), „Acta Apostolicae Sedis” 90 (1998), s. $177-193$.

Paulus PP. VI, Constitutio Apostolica Vicariae potestatis in Urbe (6 gennaio 1977), "Acta Apostolicae Sedis” 69 (1977), s. 5-18.

Pontificia Commissio Codici Iuris Canonici Recognoscendo, Opera Consultorum in parandis canonum schematibus, II: De Clericis - De Sacra Hierarchia, „Communicationes" 5 (1973), s. 216-235.

Pontificia Commissio Codici Iuris Canonici Recognoscendo, Schema De Populo Dei, Typis Polyglottis Vaticanis 1977, tekst polski: Posoborowe prawodawstwo kościelne, zebrał i przetłumaczył E. Sztafrowski, t. 10, z. 2, Warszawa 1979, s. 125-388.

Regulamin Kurii Diecezjalnej w Tarnowie (31 grudnia 2010), „Currenda” 161 (2011) $\mathrm{nr} 1$, s. 63-77.

Regulamin Kurii Metropolitalnej Warszawskiej (24 czerwca 2008), archwwa.net/wp-content/uploads/2016/04/regulamin (10.05.2017).

Regulamin Legnickiej Kurii Biskupiej, w: I Synod Diecezji Legnickiej (2007-2012), t. 1: Program odnowy religijno-moralnej, Legnica 2012, s. 278-303.

Schema Codicis Iuris Canonici, Libreria Editrice Vaticana 1980.

Statut Kurii Metropolitalnej Poznańskiej (14.06.2008), w: LXIX Synod Archidiecezji Poznańskiej (2004-2008), t. 2: Statuty, Poznań 2008, s. 391-402.

Statut Kurii Metropolitalnej Wrocławskiej (9.12.2013), http://www.archidiecezja.wroc.pl (10.05.2017).

Statuto della Curia Diocesana della diocesi di Albenga-Imperia, http://repertoriogiuridico.chiesacattolica.it/statuto-della-curia-della-diocesi-di-albenga-imperia, (3.06.2017). 


\section{Literatura}

Arrieta J., Diritto dellorganizzazione ecclesiastica, Milano 1997.

Aymans W., Der Leitungsdienst des Bischofs im Himblick auf die Teilkirche. Über die bischöfliche Gewalt und ihre Ausübung auf Grund des Codex Iuris Canonici, „Archiv für katholisches Kirchenrecht" 153 (1984), s. 35-55.

Bux P., Direzione e coordinamento delle attività nella Curia Diocesana, Roma 1995.

The canon law letter and spirit a practical guide to the code of canon law. Prepared by the canon law society of Great Britain and Ireland in association with The Canadian Canon Law Society, ed. by F. Morrisey, London 1999.

Comentario exegético al Código de Derecho Canónico, obra dirigida y coordinada por A. Marzoa, J. Miras, R. Rodríguez-Ocaña, vol. 2, Pamplona 1996 63, s. 1333.

Commento al Codice di Diritto Canonico, a cura di P. Pinto, Roma 1985.

Conlon R., The Moderator of the Curia as Manager of the Diocesan Pastoral Action, Ottawa 1987.

New Commentary on the Code of Canon Law, ed. by J. Beal, J. Coriden, T. Green, New York 2000.

Giuliani G., I canoni generali sulla Curia diocesana, „Apollinaris” 61 (1988) n. 1-2, S. $109-153$.

Howes R., Moderator of the Curia: new boy in Town!, „The Jurist” 40 (1982), s. 517-524. Jougan A., Słownik kościelny łacińsko-polski, Warszawa 1992.

Karambai S., Ministers and Ministries in the Local Church. A Comprehensive Guide to Ecclesiastical Norms, Mumbai 2005.

Komentarz do Kodeksu Prawa Kanonicznego. T. 2. Ks. II (1). Lud Boży, red. J. Krukowski, Poznań 2005.

Krukowski J., Struktura kurii diecezjalnej według nowego Kodeksu Prawa Kanonicznego, „Kościół i Prawo” 6 (1989), s. 43-55.

Marchetti G., La curia come organo di partecipazione al ministero pastorale del vescovo diocesano, „Periodica de re canonica” 89 (2000) fasc. 4, s. 566-572.

McDonough K., The Moderator of the Curia and Curial Coordination, Romae 1987.

Mendonca A., The structural components of the diocesan curia, http://www.canonlawsocietyindia.org (2.06.2017).

Pagé R., Les Églises particulières, t. 1, Montréal 1985.

Perlasca A., La funzione notarile del cancelliere e degli altri notai della curia, „Quaderni di diritto ecclesiale" 14 (2001) n. 2, s. 128-143.

Rayappan A., The Office of the Vicar General and Episcopal Vicar, http://www.canonlawsocietyindia.org (2.06.2017). 
Redaelli C., La Curia Diocesana: natura e articolazioni, „La Scuola Cattolica” 120 (1992) n. 2-3, s. 172-194.

Redaelli C., Natura e compiti della Curia diocesana, „Quaderni di diritto ecclesiale” 7 (1994) n. 2, s. 140-153.

Rivella M., Il funzionamento delle Curie diocesane in Italia, „Quaderni di diritto ecclesiale" 7 (1994) n. 2, s. 176-183.

Rouco Varela A., El ministerio Episcopal y la organización de la curia w: La curia Episcopal: reforma y actualización, Salamanca 1979, s. 11-34.

San Josè Prisco J., Moderator de la curia diocesana, w: Diccionario General de Derecho Canónico, obra dirigida y coordinada por J. Otaduy, A. Viana, J. Sedano, vol. 5 , Pamplona 2012, s. 445-446.

Wilemska E., Moderator w prawie kanonicznym, w: Encyklopedia katolicka, t. 12, red. E. Ziemann, Lublin 2008, k. 1491-1492. 